\title{
A importância da implementação do Comitê de Auditoria para Organizações Sociais: o caso de uma Organização Social vinculada ao Governo Federal
}

\author{
Nome Maria Gabriela Monici \\ Instituição/Afiliação Universidade Brasília (UnB) \\ País Brasil \\ Resumo da Bacharel em Ciências Contábeis pela UnB \\ Biografia \\ Nome \\ Abimael de Jesus Barros Costa \\ Instituição/Afiliação Universidade Brasília (UnB) \\ País \\ Resumo da \\ Biografia \\ Brasil \\ É professor do Departamento de Ciências Contábeis e Atuariais e do Programa de \\ Pós-graduação em Ciências Contábeis (PPGCont) da Universidade de Brasília \\ (UnB), em estágio pós-doutoral em Contabilidade Pública na Universidade de \\ Valência/Espanha (2019-2020). Doutor em Engenharia de Transportes, área \\ Economia dos Transportes, no PPGT do Departamento de Engenharia Civil e \\ Ambiental, Mestre em Contabilidade (PPGMI/UnB/UFRN/UFPB), bacharel, \\ especialista e técnico em Contabilidade, possui complementação didática em \\ Matemática e Pedagogia. Ex-Diretor Executivo do Centro de Seleção e de \\ Promoção de Eventos (CESPEUnB). Ex-Auditor-Chefe do Cebraspe. É avaliador \\ do Sistema Nacional de Avaliação da Educação Superior - INEP. Áreas de \\ interesse: Governo; Finanças Públicas; Contabilidade Aplicada ao Setor Público \\ (CASP); Controle da Administração Pública; Governança Regulatória; Educação e \\ Pesquisa em Contabilidade.
}

Contato principal para correspondência.

\section{RESUMO}

As entidades do terceiro setor, chamadas Organizações Sociais, cujas atividades são dirigidas ao ensino, à pesquisa científica, ao desenvolvimento tecnológico, à proteção e preservação do meio ambiente, à cultura e à saúde tem um modelo híbrido de governança. Nesse tocante, a criação de um Comitê de Auditoria contribui como um órgão de assessoramento ao Conselho de Administração. Assim sendo, este estudo tem como objetivo analisar a opinião dos diretores e membros do Conselho de Administração sobre a importância da criação de um Comitê de Auditoria para uma entidade do terceiro setor e foi baseado no trabalho de Furuta e Santos (2010). A coleta de dados foi feita por meio de aplicação de questionários por correio eletrônico. A constituição de Comitê de Auditoria foi avaliada por $67 \%$ dos colaboradores da pesquisa como dispensável, caso o Conselho Fiscal fosse capaz de exercer suas funções. Já como aspectos positivos da criação do comitê, os executivos apontaram: trazer credibilidade ao controle e a qualidade das demonstrações contábeis e alcançar maiores níveis de governança corporativa. Por isso, concluiu-se que a instalação do Comitê de Auditoria não é prioridade apesar da contribuição para melhoria da Governança da OS estudada. Por fim, percebe-se que os relatórios de gestão anuais das organizações sociais focam em alcançar metas e em detrimento de apresentar a qualidade da gestão.

Palavras-chave: Comitê de Auditoria; Organização Social; Governança Corporativa; Governança Pública. 


\section{Contabilidade}

\section{INTRODUÇÃO}

A evolução da administração pública brasileira foi marcada por uma proposta de reforma organizacional e cultural, visando o seu reposicionamento, a qual tem se materializado, principalmente, por meio de um discurso associado à redução do seu papel. Essa ideia de redução do seu papel pode ser feita por meio da delegação dos seus serviços por parte do governo. Segundo Meirelles (2001), serviço público é todo aquele prestado pela Administração ou por seus delegados, sob normas e controles estatais, para satisfazer necessidades essenciais ou secundárias da coletividade, ou simples conveniência do Estado. Ou seja, é formada uma relação de parceria entre o Estado e as empresas privadas, para que elas forneçam esses serviços à comunidade.

Levando as informações anteriormente citadas em consideração, este estudo propõe analisar a parceria estabelecida entre a Administração Pública e as entidades do terceiro setor, chamadas Organizações Sociais. Segundo Figueiredo (2003), uma O.S. se caracteriza por ser pessoa jurídica privada, sem fins lucrativos, cuja atividades, no âmbito federal, são dirigidas ao ensino, à pesquisa científica, ao desenvolvimento tecnológico, à proteção e preservação do meio ambiente, à cultura e à saúde.

Esse modelo híbrido de governança, que combina esferas pública e privada, é celebrado por meio de contratos de gestão. A parceria proporciona melhoria na prestação de serviços à comunidade, que são prestados com maior eficiência e menor custo, gerando maior autonomia gerencial às organizações, de acordo com Nóbrega (2000).

Ainda segundo o autor, dessa forma, o Estado deixa de atuar como executor e passaria a ser fiscalizador e investidor destes serviços. Para garantir o controle adequado, é recomendado pelo Instituto Brasileiro de Governança Corporativa (IBGC), a criação de um Comitê de Auditoria. De acordo com o instituto, esse é o órgão de assessoramento ao conselho de administração, que auxilia no controle sobre a qualidade de demonstrações financeiras e controles internos, visando a confiabilidade e integridade das informações para proteger a organização e todas as partes interessadas. Ou seja, auxilia no monitoramento do cumprimento das leis, regulamentos e sistemas de conformidade; na supervisão da estrutura e das atividades de gerenciamento de riscos; dos aspectos de ética e conduta e eventual existência de fraude; da qualidade do processo contábil; supervisão das atividades da auditoria interna; e suporte ao conselho na contratação ou substituição do auditor independente (IBGC, 2015).

Portanto, este estudo se propõe a analisar a importância da criação do Comitê de Auditoria em uma entidade de terceiro setor para otimizar a verificação do cumprimento das 
normas e sugerir a implementação das boas práticas de governança pública e privada. Desta forma, pretende-se relacionar a importância do comitê com as percepções dos conselheirose executivos de uma Organização Social Federal por intermédio da coleta de dados por meio da aplicação de questionário.

O IBGC entende que o Conselho Fiscal, por sua vez, representa um mecanismo de fiscalização independente dos administradores cujo objetivo é preservar o valor da organização.

Ainda de acordo com o instituto, o Conselho Fiscal não substitui o comitê de auditoria. Enquanto este último é órgão de controle com funções delegadas pelo conselho de administração, aquele é instrumento de fiscalização eleito pelos sócios e, por lei, não se subordina ao conselho de administração.

Nos Estados Unidos, em 30 de julho de 2002, foi criada a Lei Sarbanes-Oxley (SOX), que tornou obrigatória a implantação do Comitê de Auditoria, entre outras medidas. Sua criação, em decorrência aos vários escândalos ocorridos em grandes empresas norteamericanas, teve por objetivo estabelecer maior transparência na divulgação de informações econômico-financeiras, maior rigor nos procedimentos de controle interno e atribuir maior responsabilidade aos principais executivos. A legislação determina que não só as empresas norte-americanas estão sujeitas à essa condição, como também aquelas que não são, mas possuem cotação secundária em uma Bolsa de Valores dos EUA.

Já no Brasil, é possível optar pela formação do Comitê de Auditoria ou pela utilização do Conselho Fiscal adaptado às funções do mesmo. É de se esperar que os gestores de todas as entidades prezem por uma boa governança. Considerando o contexto atual da administração pública do Brasil, onde cada vez mais os órgãos fiscalizadores tomam medidas em prol da transparência e da eficiência administrativa, as instruções de boas práticas de governança também são direcionadas para as Organizações Sociais, que são pessoas jurídicas de direito privado, sem fins lucrativos, instituídas por iniciativa de particulares, para desempenhar serviços sociais não exclusivos do Estado, com incentivo e fiscalização pelo Poder Público, mediante vínculo jurídico instituído por meio de contrato de gestão (DI PIETRO, 2002).

Para que se tenha uma prestação de serviço de qualidade, por parte da organização social, realizada de forma clara, transparente, e com a garantia de que os recursos estão sendo aplicados de forma adequada, é necessária a existência de controle e fiscalização, já realizados por parte da auditoria interna e externa. Além disso, na literatura especializada, o fenômeno estudado nesta pesquisa já foi explorado sob o olhar do mundo corporativo no que se refere às características do Comitê de Auditoria (Santos, Schmeider e Cunha, 2017), os efeitos do Comitê 
de Auditoria na qualidade da informação contábil (Baioco e Almeida, 2017) e na perspectiva do prazo de publicação dos demonstrativos financeiros (Cunha, Pletsch e Silva, 2015).

Nesta perspectiva, a presente pesquisa respondeu o seguinte problema: de que forma os conselheiros e executivos de uma Organização Social Federal (OS) percebem a contribuição do Comitê de Auditoria para a governança da OS? O estudo tem como objetivo geral obter a opinião dos diretores e membros do Conselho de Administração sobre a importância do Comitê de Auditoria em uma Organização Social. Para tanto, foi necessário alcançar os seguintes objetivos específicos: a) avaliar se o Comitê de Auditoria é um órgão dispensável ou indispensável na opinião dos gestores de uma Organização Social; b) descrever as peculiaridades do modelo híbrido de governança em que as Organizações Sociais se encaixam; c) explicar como a criação de um Comitê de Auditoria pode contribuir para a boa governança de uma Organização Social.

A motivação para realizar a pesquisa surgiu da carência de trabalhos que destaquem a importância de um órgão como o Comitê de Auditoria em um cenário de entidades do terceiro setor, considerando pesquisa realizada no portal CAPES periódicos. Artigos anteriores, como o estudo de Furuta e Santos (2010), já foram capazes de verificar as percepções de analistas de mercado e executivos do universo corporativo sobre o tema.

A maior parte do arcabouço científico que trata sobre as Organizações Sociais aborda aspectos jurídicos relacionados à constituição de uma O.S. e características dos contratos de gestão. Há uma necessidade, no contexto acadêmico, de abordar uma perspectiva de técnicas de governança aplicadas a essas entidades.

Acredita-se que a pesquisa realizada contribui para futuros trabalhos com enfoque ao papel do Comitê de Auditoria como um recurso de gestão pública, já que, a partir do momento em que uma O.S. estabelece uma parceria com o governo, ela passa a ser alvo de fiscalização, necessitando, portanto, de instrumentos de transparência e controle social. Este trabalho foi elaborado para aprofundar o entendimento sobre as Organizações Sociais, suas funções para a sociedade, a legalidade do contrato de gestão, a necessidade de criação do Comitê de Auditoria e boas práticas de governança.

$\mathrm{Na}$ introdução consta a apresentação de um apanhado geral do conteúdo do artigo científico. Ou seja, é a breve descrição da importância da área de estudo, destacando a especificidade do tema, a relevância problemática e os objetivos a serem alcançados. O referencial teórico aborda questões como: o conceito e a origem das Organizações Sociais, algumas informações sobre cada O.S. existente no Brasil, como funciona o modelo híbrido de 


\section{Revista \\ UNEMAT de \\ Contabilidade}

v. 8, n. 16,2019

governança de uma entidade do terceiro setor que celebra contratos de gestão com o governo e atua em interesse comum de toda a coletividade, além disso, destaca a utilidade do Comitê de Auditoria dentro de uma instituição com essas características.

A metodologia trata sobre a aplicação de um questionário aos diretores e membros do Conselho de Administração de uma Organização Sociais Federal. A análise dos dados é uma reflexão sobre as respostas recebidas após a solicitação de preenchimento do questionário. E por último, as considerações finais serão compostas por um breve relato os resultados da pesquisa, se os objetivos foram de fato alcançados, e indicações para futuras pesquisas sobre o assunto.

\section{FUNDAMENTAÇÃO TEÓRICA}

2.1. Modelo Híbrido de Governança: privada versus pública

Sabe-se que as primeiras práticas de governança surgiram nas empresas privadas, com o objetivo de potencializar o desempenho da organização e reduzir os desequilíbrios entre os interesses de proprietários e gestores. O primeiro passo foi dado com a publicação do Código das Melhores Práticas de Governança Corporativa na Inglaterra, nomeado Internal Control integrated framework, de 1992, como forma de combate às crises financeiras da época por parte do Comitte os Sponsoring Organizations of the Treadway Commision (COSO).

Logo após a onda de escândalos corporativos nos Estados Unidos em 2002, surgiu também uma preocupação com a qualidade das demonstrações contábeis publicadas pelas empresas. A Lei Sarbanes-Oxley foi criada com o intuito de aperfeiçoar os controles e evitar que mais escândalos ocorressem.

No Brasil, o Instituto Brasileiro de Governança Corporativa - IBGC, desde 2004, lança novas versões de seu Código das Melhores Práticas de Governança Corporativa. O documento é dividido na apresentação de quatro tópicos: transparência, equidade, prestação de contas (accountability) e responsabilidade corporativa. O código tem o objetivo de se tornar mais abrangente e adaptável possível, para que possa ser aplicado tanto no contexto corporativo quanto na administração pública. Ou seja, levando em consideração as peculiaridades de cada uma, as recomendações podem servir de contribuição para outros tipos de organizações além das empresas privadas, como instituições do terceiro setor, cooperativas, estatais (empresas públicas e sociedades de economia mista), por exemplo.

É oportuno destacar também a importância de duas leis que foram criadas no Brasil afim de trazer melhorias para a governança pública: a Lei de Responsabilidade Fiscal (Lei 
Complementar 101, de 4 de maio de 2000) e a Lei de Acesso à Informação (Lei 12.527, de 18 de novembro de 2011).

A Lei de Responsabilidade Fiscal surgiu como uma importante ferramenta de controle de gastos e transparência das contas públicas. De acordo com STN (2019) a lei estabelece, em regime nacional, parâmetros a serem seguidos relativos ao gasto público de cada ente federativo (estados e municípios) brasileiro.

As restrições orçamentárias visam preservar a situação fiscal dos entes federativos, de acordo com seus balanços anuais, com o objetivo de garantir a saúde financeira de estados e municípios, a aplicação de recursos nas esferas adequadas e uma boa herança administrativa para os futuros gestores.

Entre seus itens está previsto que cada aumento de gasto precisa vir de uma fonte de financiamento correlata e os gestores precisam respeitar questões relativas ao fim de cada mandato, não excedendo o limite permitido e entregando contas saudáveis para seus sucessores.

Segundo STN (2019), a Lei 12.527/2012 regulamenta o direito constitucional de acesso às informações públicas. Essa norma entrou em vigor em 16 de maio de 2012 e criou mecanismos que possibilitam, a qualquer pessoa, física ou jurídica, sem necessidade de apresentar motivo, o recebimento de informações públicas dos órgãos e entidades.

A Lei 12.527/2012 vale para os três Poderes da União, Estados, Distrito Federal e Municípios, inclusive aos Tribunais de Contas e Ministério Público. Entidades privadas sem fins lucrativos também são obrigadas a dar publicidade a informações referentes ao recebimento e à destinação dos recursos públicos por elas recebidos.

As duas leis são os principais instrumentos de governança da atual administração pública. Em vigor, proporcionam a prática de prestação de informação por porte do governo à população e a transparência da destinação dos recursos. Dessa forma, a Lei de Acesso à Informação permite maior controle social e a Lei de Responsabilidade Fiscal proporciona o combate à corrupção, o que as torna importantes armas contra a má gestão pública.

No caso das Organizações Sociais, que, mesmo sendo caracterizadas como instituições privadas, são alvos de fiscalização, já que são beneficiadas com recursos fornecidos pelo governo, constitui-se um novo modelo de governança.

Esse modelo híbrido utiliza uma combinação dos mecanismos de governança pública e privada. Para entender melhor essa peculiaridade do contexto em que se inserem as Organizações Sociais, é preciso antes compreender esses dois universos. 
O Quadro 1 retrata os principais itens de cada um deles, oferecendo suporte para a compreensão da pesquisa deste trabalho.

\begin{tabular}{|c|c|c|}
\hline & $\begin{array}{l}\text { GOVERNANÇA } \\
\text { CORPORATIVA }\end{array}$ & $\begin{array}{l}\text { GOVERNANÇA } \\
\text { PÚBLICA }\end{array}$ \\
\hline CONCEITO & $\begin{array}{l}\text { "Governança corporativa é o sistema } \\
\text { pelo qual as empresas e demais } \\
\text { organizações são dirigidas, monitoradas } \\
\text { e incentivadas, envolvendo os } \\
\text { relacionamentos entre sócios, conselho } \\
\text { de administração, diretoria, órgãos de } \\
\text { fiscalização e controle e demais partes } \\
\text { interessadas." } \\
\text { (Código das melhores práticas de } \\
\text { governança corporativa - IBGC 2015) }\end{array}$ & $\begin{array}{l}\text { "Governança no setor público } \\
\text { compreende essencialmente os } \\
\text { mecanismos de estratégia e controle } \\
\text { postos em prática para avaliar, } \\
\text { direcionar e monitorar a atuação da } \\
\text { gestão, com vistas à condução e } \\
\text { políticas públicas e à prestação de } \\
\text { serviços de interesse da sociedade." } \\
\text { (Referencial Básico de Governança - } \\
\text { TCU 2013) }\end{array}$ \\
\hline FUNÇÃO & $\begin{array}{l}\text { Melhorar desempenho organizacional, } \\
\text { reduzir conflitos de interesses entre } \\
\text { proprietários e administradores, alinhar } \\
\text { ações e trazer segurança para os sócios. }\end{array}$ & $\begin{array}{l}\text { Tornar o Estado mais eficiente, ético e } \\
\text { focado no alcance de resultados que } \\
\text { estejam alinhados com as expectativas } \\
\text { da sociedade. }\end{array}$ \\
\hline $\begin{array}{l}\text { EFEITO/ } \\
\text { CONSEQUÊNCIA }\end{array}$ & $\begin{array}{l}\text { Reduz assimetria da informação entre } \\
\text { agente e principal, protege investidores, } \\
\text { garante ordem e eficácia dos mercados e } \\
\text { facilita a formação de capital. }\end{array}$ & $\begin{array}{l}\text { Promove eficiência administrativa, } \\
\text { transparência na gestão pública, } \\
\text { incentiva o controle social e a } \\
\text { responsabilização dos gestores públicos. }\end{array}$ \\
\hline PRINCIPAL-AGENTE & Proprietários-Administradores & Cidadãos-Colaboradores Públicos \\
\hline
\end{tabular}

Fonte: elaborado pelos autores baseado no Código das melhores práticas de governança corporativa - IBGC (2015) e no Referencial Básico de Governança - TCU (2013).

Analisando as informações do Quadro 1, pode-se perceber que os dois conceitos de governança são aplicáveis a uma Organização Social. Como empresa privada, é importante que o conselho de administração e a diretoria estejam bem alinhados e visem o bom desempenho e a longevidade da instituição. Isso se torna ainda mais essencial quando estabelecem uma relação de parceria com o Estado, por meio de um contrato de gestão. Já que a execução das suas atividades não afeta só os envolvidos no contrato, e sim toda a comunidade, que será usuária dos serviços prestados. É por meio desse contrato que serão estabelecidos meios para avaliar, direcionar e monitorar a atuação da gestão. $\mathrm{O}$ órgão responsável por fiscalizar e avaliar os resultados obtidos pela O.S. é aquele que contratou seus serviços.

E da mesma forma que a Organização Social precisa utilizar de boas práticas de governança para melhorar o desempenho organizacional, ela também necessita que suas atividades estejam focadas em alcançar as metas estabelecidas no contrato de gestão, oferecendo, assim, um bom serviço para a sociedade. 
O assunto se torna mais claro com a aplicação dos Princípios Básicos de Governança Corporativa propostos pelo IBGC (ano):

- Transparência

De acordo com o instituto, é preciso disponibilizar aos usuários da informação (stakeholders) todas as informações relevantes e que sejam de seu interesse, e não apenas aquelas impostas pela regulamentação.

- Equidade

Esse princípio trata sobre o tratamento justo e isonômico de todos os usuários da informação, levando em consideração seus direitos, deveres, necessidades, interesses e expectativas.

- Prestação de Contas (accountability)

A accountability é um mecanismo de controle que visa auferir a legitimidade aos resultados da organização (SHEDLER, 1999). Para que isso se torne possível, não basta que a informação esteja disponível, é necessário que ela seja pública, tempestiva, detalhada e precisa.

Dessa forma, a prestação de contas permite que sejam feitos dois tipos de controle: o controle administrativo (órgãos fiscalizadores) e o controle social (população).

- Responsabilidade Corporativa

Os administradores de uma organização devem zelar pela viabilidade econômicofinanceira das organizações. Quando se trata de administração pública, são criados vários instrumentos para garantir o controle de gastos e a fiscalização dos envolvidos na gestão. Iniciando assim, o combate à corrupção e a responsabilização dos gestores públicos. Por fim, esses aspectos devem ser explorados à luz da literatura especializada na perspectiva das organizações do setor privado, sem fins lucrativos e no setor público.

As características do conselho de administração e do comitê de auditoria das empresas listadas na BM\&FBovespa foram estudadas por Reyes, Cunha e Cecon (2018). Eles por intermédio de uma pesquisa descritiva, de cunho quantitativo e com procedimento de coleta de dados documental exploraram o tema. A amostra do estudo resultou em 1620 conselhos de administração e 399 comitês de auditoria. A principal constatação da pesquisa foi que, em média, os conselhos de administração possuem entre 6 e 12 conselheiros, maioria de membros independentes e de 3 a 8 membros com expertise. Concluiu-se que quanto maior o tamanho do conselho, com mais membros independentes e com expertise, menor será a possibilidade de dualidade. E, além disto, os resultados indicam que o tamanho do comitê de auditoria está 
positivamente relacionado com a quantidade de membros com expertise (REYES, CUNHA e CECON, 2018).

Santos, Schmeider e Cunha (2017) pesquisaram as características de tamanho, independência e expertise dos comitês de auditoria das empresas listadas na BM\&FBovespa nos anos de 2010 a 2013. Dentre as 407 empresas listadas na bolsa de valores, apenas 68 delas possuem comitê de auditoria devidamente formado em algum período analisado. Em 2013, existiam 192 membros dos comitês de 59 empresas. Desses, 48 são engenheiros, 45 economistas, 41 administradores, 26 contadores e um auditor. De modo geral, conclui-se que a criação do comitê de auditoria, ainda, não é uma prática institucionalizada pelas empresas brasileiras e que se manifesta de formas distintas entre as organizações (SANTOS, SCHMEIDER e CUNHA, 2017).

Por outro lado, a identificação de quais características do comitê de auditoria estão relacionadas com a qualidade da auditoria independente, nas empresas listadas nos níveis diferenciados de governança corporativa da BM\&FBovespa foram estudadas por Teixeira, Camargo e Vicente (2016). Os dados dessa pesquisa foram obtidos nos relatórios públicos de 57 empresas do ano de 2013 e analisados por meio de regressão linear múltipla. Concluiu-se que as empresas com Comitê de Auditoria, responsáveis pela eficiência e eficácia dos controles internos, tendem a apresentar auditoria de menor qualidade (TEIXEIRA, CAMARGO e VICENTE, 2016).

Por fim, na perspectiva internacional, Rendon e Garcia (2015) abordaram o tema ao estudar os princípios da norma internacional ISO 26000 (2010) e verificar a relação entre responsabilidade social e as regras de controle interno estabelecido pela administração das organizações, bem como a relação entre a Responsabilidade Social Corporativa com o Conselho de Administração e o Comitê de Auditoria. Para alcançar o exposto, foi tomado como base um estudo das empresas que negociaram no mercado de ações mexicano em 2011. As variáveis são estudadas por meio de uma análise correlacional pelo método do qui-quadrado. Dentre as principais conclusões deste trabalho, vale destacar que as empresas estudadas apresentam alto nível de cumprimento dos princípios diretamente relacionados às regulamentações legais e às regras desse mercado, mas não aos princípios de adoção voluntária. Por outro lado, as empresas que se preocupam com a observância das leis fortalecem os aspectos de governança dentro delas (RENDON e GARCIA, 2015). 


\subsection{As Organizações Sociais Federais}

O Estado é responsável por oferecer à comunidade serviços básicos, os quais possibilitam melhores condições de vida. Essa prestação de serviço, proporcionada pelo governo de forma direta ou indireta, por vezes não é suficiente para atender a grande demanda. Na busca de suprir as necessidades da sociedade por serviços básicos, bem como diminuir suas atribuições, segundo Coutinho (2006), a administração pública delega as prestações dessas atividades para particulares, como por exemplo, entidades do terceiro setor.

Coutinho (2006) também explica que o terceiro setor está dividido da seguinte forma: em Organizações Sociais (entidades sem fins lucrativos que desenvolvem atividades relacionadas ao ensino, à pesquisa científica, ao desenvolvimento tecnológico, ao meio ambiente, à cultura e à saúde) e em Organizações da Sociedade Civil de interesse público (entes que desempenham atividades e importância social, tais como combate à pobreza, assistência social, promoção da saúde, da cultura e da cidadania). Esse estudo não abrangerá parcerias com os dois tipos de entidades do terceiro setor, mas apenas aquelas estabelecidas com as Organizações Sociais.

Segundo a Lei n. ${ }^{\circ}$ 9.637/98 (Lei das Organizações Sociais), as O.S.s são todas as associações por natureza, de direito privado, sem fins lucrativos, cujas atividades sejam dirigidas ao ensino, à pesquisa científica, ao desenvolvimento tecnológico, à proteção e preservação do meio ambiente, à cultura e à saúde.

Ainda segundo a mesma Lei, a O.S. deve possuir um conselho de administração e uma diretoria definidos nos termos do estatuto, e sua composição deve incluir membros do poder público. O IBGC (2015, p. 39) define Conselho de Administração da seguinte maneira:

O conselho de Administração é o órgão colegiado encarregado do processo de decisão de uma organização em relação ao seu direcionamento estratégico. Ele exerce o papel de guardião dos princípios, valores, objeto social e sistema de governança da organização, sendo seu principal componente.

Dessa forma, entende-se que o Conselho de administração é o órgão responsável por preservar a saúde financeira da organização e, além disso, direcionar as estratégias para agregar valor econômico à empresa. Apesar de essa ser sua função, os conselheiros podem contar com o assessoramento de outros órgãos, como por exemplo, o Comitê de Auditoria.

Portanto, apesar de assumirem a prestação de serviços públicos para a sociedade, as Organizações Sociais não fazem parte da Administração pública. Dessa forma, as entidades devem se submeter ao seu poder discricionário para serem autorizadas a atuar como O.S.s. A 


\section{Revista \\ UNEMAT de \\ Contabilidade}

v. 8, n. 16,2019

Lei n. ${ }^{\circ}$ 9.637/98 destaca alguns requisitos que as entidades precisam atender para receber esse título. De acordo com a legislação, a empresa precisa necessariamente não ter fins lucrativos; ter personalidade jurídica; ter registrado ato construtivo; estar em funcionamento ativo; disponibilizar seus serviços para a comunidade; constituir Conselho de Administração e Diretoria, com participação de representantes da Administração pública; não remunerar cargos de sua diretoria; e, publicar anualmente relatórios financeiros e de execução do contrato de gestão.

A partir da interpretação da Lei das Organizações Sociais, percebe-se que a pessoa jurídica deve adequar o seu estatuto às previsões legais, ou seja, deve atender as condições do governo, exercendo atividades de interesse público assim definidos. As atividades que podem ser executadas pelas organizações sociais são: defesa e incentivo à cultura; defesa, preservação e conservação do meio ambiente; educação; saúde; pesquisa científica e desenvolvimento tecnológico.

Ainda de acordo com a Lei n. $^{\circ}$ 9.637/98, após o recebimento desse título, as organizações sociais passam a receber fomentação do Estado, em forma de recebimento de recursos públicos, assim como usufruir de isenções fiscais. A partir daí também estão autorizadas a estabelecer parcerias com o poder público para execução de suas atividades. Por essa razão, enquanto possuírem um contrato de gestão vigente com o governo federal, a organização passa a ser alvo de controle e fiscalização.

Como os serviços prestados pela organização ficam à disposição de toda a comunidade, cada cidadão se torna parte interessada de suas atividades. Como usuário do serviço, necessita da prestação de forma clara, transparente e objetiva. Para que, dessa maneira, seja possível fazer um controle social daquela atividade que está sendo oferecida, garantindo assim, a sua qualidade.

Em relação ao contrato de gestão, Rocha (2003,p.27) destaca:

É o instrumento hábil ao recebimento de recursos públicos, além de um eficiente meio de controle do desempenho das atividades e da aplicação desses recursos. Seu objetivo é estabelecer os direitos e deveres de ambas as partes, ou seja, deverá trazer as atribuições, responsabilidades, obrigações e formas de controle para o desenvolvimento dessas atividades.

O contrato, de acordo com a lei, deve observar os seguintes princípios: da legalidade (o contrato deve ter como base uma norma legal específica), da impessoalidade (não pode o contrato conter subjetividades), da moralidade, da publicidade (transparência das atividades administrativas), da economicidade (o contrato deve considerar a racionalização de custos e 
otimização de resultados). Ao estabelecer essa parceria, o governo busca a descentralização do poder, almejando maior eficiência e redução de custos.

O programa de trabalho inclui previsão de metas, prazos de execução, critérios objetivos de avaliação e limites impostos com despesas e remunerações destinadas aos dirigentes e empregados das organizações sociais. Pode prever o recebimento de recursos orçamentários e bens públicos. No caso dos bens públicos, esses serão cedidos à OS para o desenvolvimento da sua atividade, sendo dispensada a licitação mediante permissão de uso (COUTINHO, 2006).

Após estabelecido o contrato de gestão, é definido o quadro de funcionários. O Conselho de Administração e a Diretoria é formado por servidores que são cedidos pela própria administração pública e por funcionários contratados. Quando o servidor é cedido, sua remuneração não sofrerá alteração, já que não é permitido que este funcionário receba qualquer valor da entidade.

A possibilidade de colaboração de entidades do setor privado pode significar a melhoria na prestação de serviços à comunidade, que são prestados com maior eficiência e menor custo. Além de propiciar maior autonomia gerencial. Com isso, o Estado deixaria de atuar como executor e passaria a ser fiscalizador e investidor desses serviços (NÓBREGA; 2000).

Gonçalves (2005) relata que as Organizações Sociais só poderão prestar serviços não exclusivos, que são aqueles que o Estado atua ao mesmo tempo em que as organizações do setor privado e é permitido que desempenhe essas funções de forma complementar, sem substituir o dever do Estado de prestá-la.

Alguns autores defendem que esse modelo de gestão é inconstitucional. Rocha (2003) acredita que esse contrato viola o princípio constitucional da isonomia, ao dispensar a licitação para a escolha da Organização Social a ser contratada. Além disso, segundo o autor, ao ser concedido excessivo poder discricionário à Administração pública, essa age de forma equivocada ao não exigir nenhum requisito técnico ou econômico para a escolha da Organização Social, deixando-se totalmente ao critério do ministro correspondente tal decisão.

Outra autora que segue essa linha de pensamento é Di Pietro (2002), quando aponta em sua pesquisa os principais problemas relacionados ao contrato de gestão: a delegação de serviço público exclusivo do Estado ao particular; a concessão de grande liberdade ao particular e o pouco controle de suas atividades e do destino do patrimônio público que lhe é atribuído; a discricionariedade do administrador tanto na concessão do título de OS, quanto no contrato de gestão; a desobediência aos princípios constitucionais norteadores da administração pública (ausência de licitação). 
O Brasil, até 2017, possuía 8 (oito) Organizações Sociais Federais, sendo que 6 (seis) delas estão vinculadas ao Ministério da Ciência, Tecnologia e Inovação - MCTI e 2 (duas) ao Ministério da Educação - MEC. A seguir a descrição sucinta de cada uma delas. Todas elas estão representadas no Quadro 2 :

Quadro 2: Organizações Sociais do Governo Federal

\begin{tabular}{|c|c|c|c|c|c|c|}
\hline Nome & $\begin{array}{l}\text { Ano de } \\
\text { criação }\end{array}$ & Vinculação & $\begin{array}{l}\text { Decreto de } \\
\text { qualificação }\end{array}$ & Sede & $\begin{array}{l}\text { Contrato de } \\
\text { gestão }\end{array}$ & Linha de ação \\
\hline CGEE & 2001 & MCTI & 2002 & $\begin{array}{l}\text { Brasília - } \\
\text { DF }\end{array}$ & $\begin{array}{l}\text { Vigente } \\
\text { desde } \\
2002\end{array}$ & $\begin{array}{l}\text { Promoção e realização de estudos } \\
\text { e pesquisas prospectivas na área de } \\
\text { ciência e tecnologia e atividades } \\
\text { de avaliação de estratégias e de } \\
\text { impactos econômicos e sociais das } \\
\text { políticas. }\end{array}$ \\
\hline $\begin{array}{l}\text { CNPEM/ } \\
\text { ABTLuS }\end{array}$ & 1997 & MCTI & 1997 & $\begin{array}{l}\text { Campinas } \\
\text { - SP }\end{array}$ & $\begin{array}{l}\text { Vigente } \\
\text { desde } \\
2010\end{array}$ & $\begin{array}{l}\text { Integração de competências } \\
\text { singulares em Laboratórios } \\
\text { Nacionais para o desenvolvimento } \\
\text { científico e tecnológico e apoio à } \\
\text { inovação em energia, materiais e } \\
\text { biociências. }\end{array}$ \\
\hline IDSM & 1999 & MCTI & 1999 & Tefé -AM & $\begin{array}{l}\text { Vigente } \\
\text { desde } \\
2001\end{array}$ & $\begin{array}{l}\text { Conservação da biodiversidade } \\
\text { com o manejo participativo e } \\
\text { sustentável dos recursos naturais } \\
\text { na Amazônia. }\end{array}$ \\
\hline IMPA & 1951 & MCTI & 2000 & $\begin{array}{l}\text { Rio de } \\
\text { Janeiro - } \\
\text { RJ }\end{array}$ & $\begin{array}{l}\text { Vigente } \\
\text { desde } \\
2001\end{array}$ & $\begin{array}{l}\text { Colaborar com a implementação } \\
\text { do Programa Expansão e } \\
\text { Consolidação do Conhecimento } \\
\text { Científico e Tecnológico. }\end{array}$ \\
\hline RNP & 1989 & MCTI & 2002 & $\begin{array}{l}\text { Rio de } \\
\text { Janeiro - } \\
\text { RJ }\end{array}$ & $\begin{array}{l}\text { Vigente } \\
\text { desde } \\
2002\end{array}$ & $\begin{array}{l}\text { Execução de atividades de } \\
\text { pesquisas tecnológicas em redes, } \\
\text { de desenvolvimento e operação de } \\
\text { meios e serviços de redes } \\
\text { avançadas e do desenvolvimento } \\
\text { tecnológico na área de redes. }\end{array}$ \\
\hline EMBRAPII & 2013 & MCTI & 2013 & $\begin{array}{l}\text { Brasília - } \\
\text { DF }\end{array}$ & $\begin{array}{l}\text { Vigente } \\
\text { desde } \\
2013\end{array}$ & $\begin{array}{l}\text { Promoção e incentivo a realização } \\
\text { de projetos empresariais de } \\
\text { pesquisa, desenvolvimento e } \\
\text { inovação voltados para setores } \\
\text { industriais por meio de cooperação } \\
\text { com instituições de pesquisa } \\
\text { tecnológica. }\end{array}$ \\
\hline Cebraspe & 1993 & MEC & 2013 & $\begin{array}{l}\text { Brasília - } \\
\text { DF }\end{array}$ & $\begin{array}{l}\text { Vigente } \\
\text { desde } \\
2014\end{array}$ & $\begin{array}{l}\text { Realização de atividades de gestão } \\
\text { de programas, projetos, apoio } \\
\text { técnico e logístico para subsidiar } \\
\text { sistemas de avaliação educacional. }\end{array}$ \\
\hline ACERP & 1967 & MEC & 2014 & $\begin{array}{l}\text { Rio de } \\
\text { Janeiro - } \\
\text { RJ }\end{array}$ & $\begin{array}{l}\text { Vigente } \\
\text { desde } \\
2014\end{array}$ & $\begin{array}{l}\text { Produção de soluções de } \\
\text { comunicação transformadoras, de } \\
\text { alta qualidade e economicamente } \\
\text { viáveis, especializadas no campo } \\
\text { da educação. }\end{array}$ \\
\hline
\end{tabular}

Fonte: elaborado pelos autores.

Após feita a apresentação das Organizações Sociais Federais existentes, é interessante relacionar sua trajetória (Figura 1) com outros marcos importantes da história do país: 


\section{Contabilidade}

Figura 1 - Linha do tempo sobre a trajetória das Organizações Sociais Federais

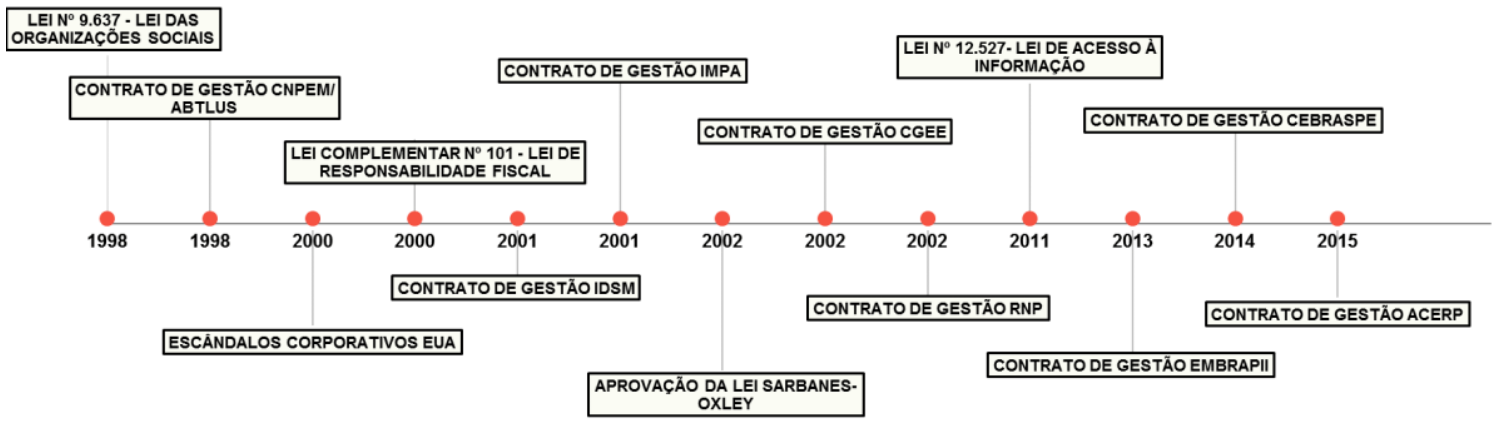

Fonte: Ministério da Ciência, Tecnologia, Inovações e Comunicações (2019)

O primeiro fato interessante para o presente estudo é a criação da Lei das Organizações Sociais. A partir de 1998, começaram a ser estabelecidos contratos de gestão entre empresas privadas e o governo brasileiro.

Com a sequência de escândalos que surgiram nos Estados Unidos e ao redor do mundo no final do século XX, os usuários da informação começaram a sentir necessidade de leis mais rigorosas.

No Brasil, foram criadas a Lei de Responsabilidade Fiscal, em 2000, e a Lei de Acesso à Informação, em 2011, como já foi citado anteriormente. Essas duas leis podem ser consideradas fatores importantes para o aumento da necessidade de melhorar as práticas de governança na administração pública.

E, nos Estados Unidos, foi criada a Lei Sarbanes-Oxley, a qual torna obrigatória a criação de um Comitê de Auditoria em determinadas empresas do país, e que também incentiva fortemente que as instituições do resto do mundo tomem essa iniciativa.

\subsection{O papel do Comitê de Auditoria}

O enfoque do comitê é a avaliação do desempenho econômico-financeiro de uma entidade, realizando a supervisão da contabilidade e dos relatórios financeiros e das auditorias das demonstrações contábeis. Para que esse trabalho seja realizado da melhor forma possível, seus membros devem ser pessoas com comprovado conhecimento técnico da área, ou seja, peritos.

Após realizado o trabalho, sob a visão do IBGC (2015), o comitê deve apresentar os relatórios ao Conselho de Administração, o qual é responsável por fiscalizar, monitorar e tomar a decisão final. Dessa forma, o comitê se torna uma peça fundamental da estrutura organizacional, tanto para manter a saúde econômica da organização quanto para promover a accountability (prestação de contas). 
A necessidade da constituição de um Comitê de Auditoria é uma ideia reforçada por Lei (Lei Sarbanes-Oxley) e por manuais sobre governança corporativa de vários órgãos (IBGC). Portanto, é importante que não se confunda o Comitê de Auditoria com Auditoria Interna nem com Auditoria Externa.

Quadro 3: Atividades desenvolvidas pelo Comitê de Auditoria

\begin{tabular}{|l|l|}
\hline 1 & Monitoramento a efetividade e da qualidade dos controles internos da organização; \\
\hline 2 & $\begin{array}{l}\text { Monitoramento do cumprimento das leis, regulamentos e sistemas de conformidade (compliance) pela } \\
\text { organização; }\end{array}$ \\
\hline 3 & $\begin{array}{l}\text { Supervisão da estrutura e das atividades de gerenciamento de riscos pela gestão da organização, incluindo os } \\
\text { riscos operacionais, financeiros, estratégicos e da imagem, em linha com as diretrizes e políticas estabelecidas } \\
\text { pelo conselho de administração; }\end{array}$ \\
\hline 4 & $\begin{array}{l}\text { Monitoramento dos aspectos de ética e conduta, incluindo a efetividade do código de conduta e do canal de } \\
\text { denúncias (abrangendo o tratamento das denúncias recebidas) e eventual existência de fraude; }\end{array}$ \\
\hline 5 & $\begin{array}{l}\text { Monitoramento da qualidade do processo contábile respectivas práticas contábeis selecionadas, da preparação } \\
\text { das demonstrações financeiras e outras informações divulgadas a terceiros; }\end{array}$ \\
\hline 6 & $\begin{array}{l}\text { Supervisão das atividades da auditoria interna, incluindo a qualidade dos seus tratamentos, estrutura existente, } \\
\text { plano de trabalho e resultados dos trabalhos realizados; }\end{array}$ \\
\hline 7 & $\begin{array}{l}\text { Suporte ao conselho de administração na contratação ou substituição do auditor independente e supervisão } \\
\text { da sua atuação, estrutura, independência perante a organização, qualidade e resultados dos seus trabalhos; }\end{array}$ \\
\hline 8 & $\begin{array}{l}\text { Avaliação e monitoramento dos controles existentes para as transações da organização com partes } \\
\text { relacionadas, bem como para sua divulgação. }\end{array}$ \\
\hline
\end{tabular}
Fonte: elaborado pelos autores baseado no IBGC (2015).

A Auditoria Interna é, pela definição do IBGC (2015, p. 91), responsável pelas seguintes atividades:

Monitorar, avaliar e realizar recomendações visando a aperfeiçoar os controles internos e as normas e procedimentos estabelecidos pelos administradores. As organizações devem possuir uma função de auditoria interna, própria ou terceirizada. A diretoria e, particularmente, o diretor-presidente também são diretamente beneficiados pela melhoria do ambiente de controles decorrente de uma atuação ativa de auditoria interna.

Entende-se, dessa forma, que sua atividade é contínua, realizada para garantir o cumprimento de políticas e normas. Se preocupa principalmente em atender as necessidades da administração e detectar ou prevenir fraudes, já que é subordinada ao Conselho de Administração.

Em relação à auditoria externa, o $\operatorname{IBGC}(2015$, p. 87) descreve que sua principal função da seguinte maneira:

Emitir, observadas as disposições aplicáveis, opinião sobre se as demonstrações financeiras preparadas pela administração representam adequadamente, em todos os seus aspectos relevantes, a posição patrimonial e financeira da organização.

$\mathrm{Ou}$ seja, os auditores devem avaliar se os controles internos utilizados pela administração são adequados e suficientes para permitir a elaboração de demonstrações 


\section{Revista \\ UNEMAT de \\ Contabilidade}

v. 8, n. 16,2019

contábeis sem distorções relevantes, sendo causadas por erros ou fraudes. A auditoria externa faz o exame das demonstrações contábeis periodicamente, geralmente semestral ou anualmente. Esse trabalho caracteriza-se principalmente pela independência em relação à administração. $\mathrm{O}$ seu principal objetivo é atender as necessidades dos stakeholders, no que diz respeito à fidedignidade das informações financeiras.

Portanto, além de possuir uma função diferente do Conselho Fiscal, como reforçado pelo IBGC (2015), o Comitê de Auditoria não se confunde com a Auditoria interna e externa.

\section{PROCEDIMENTOS METODOLÓGICOS}

Para a construção de uma base para a pesquisa deste trabalho, foi escolhido a aplicação de questionário para a coleta de dados. Ressalta-se que aspectos da pesquisa de Furuta e Santos (2010) foram replicados no presente estudo. Assim sendo, o questionário foi aplicado no intuito de constituir uma pesquisa descritiva a respeito da visão que os gestores possuem sobre as atribuições do Comitê de Auditoria e seus pontos positivos e negativos.

As questões foram elaboradas, com adaptações, a partir do estudo que compõe o artigo "Comitê de Auditoria versus Conselho Fiscal Adaptado: a visão dos analistas de mercado e dos executivos das empresas que possuem ADRs" (FURUTA e SANTOS, 2010). Assim como na pesquisa supracitada, o material enviado era composto por três tipos de perguntas: fechadas, abertas e do tipo escala Likert.

As primeiras 3 (três), que eram fechadas, questionavam se a entidade possuía um Comitê de Auditoria, quais foram os motivos que levaram à decisão de constituí-lo, caso existisse, e se, na opinião do entrevistado, sua criação era dispensável ou indispensável para a governança corporativa da organização social. A $4^{\mathrm{a}}$ e $5^{\mathrm{a}}$ perguntas eram abertas e tinham o objetivo de captar, segundo a visão dos participantes, quais eram os pontos negativos e positivos do Comitê de Auditoria. Ao final, os 4 itens restantes eram formados por afirmações, as quais os gestores deveriam avaliar e, de acordo com seu julgamento, escolher um grau de consentimento/rejeição marcando uma opção dentro de uma escala pré-estabelecida.

O primeiro passo para a coleta de dados, foi a escolha da Organização Social para a aplicação dos questionários. Entre as 8 entidades existentes no Brasil e com contrato de gestão vigente, optou-se por direcionar as perguntas aos diretores e membros do Conselho de uma 
organização que provê a integração global e a colaboração apoiada em tecnologias de informação e comunicação para a geração do conhecimento e a excelência da educação e da pesquisa.

O processo de coleta de dados foi realizado por meio de aplicação de questionário via e-mail. Este foi encaminhado para cada um dos 5 (cinco) diretores e 10 (dez) membros do Conselho de Administração da Organização Social Rede Nacional de Ensino e Pesquisa (RNP) juntamente com um termo de consentimento de livre esclarecimento, o qual informava que os dados coletados seriam utilizados em um banco de dados para análise da pesquisa de graduação em tela e que se garantia não provocar nenhum risco decorrente de sua participação na pesquisa, e diminuir possíveis desconfortos.

Após realizada a solicitação de participação aos componentes da instituição, obteve-se o retorno, com o questionário respondido, de $20 \%$ deles. Foram feitas novas tentativas, também por e-mail. Porém, o restante dos executivos não retornou os contatos ou não demonstrou interesse em participar da pesquisa.

De acordo com a página virtual da instituição, a composição da lista de colaboradores é a seguinte: Diretor-geral, Diretor de Gestão, Diretor de Engenharia e Operações, Diretor de Serviços e Soluções, Diretor de Pesquisa e Desenvolvimento. Além deles, existe o Conselho de Administração, que é composto por dez integrantes, nas qualidades de membros natos e membros eleitos.

Membros natos são constituídos por:

- Dois representantes do Ministério da Ciência, Tecnologia e Inovação (MCTI), indicados pelo ministro;

- Dois representantes do Ministério da Educação (MEC), indicados pelo ministro;

- Um representante da comunidade acadêmica, indicado pelo presidente da Sociedade Brasileira de Computação (SBC);

- Um representante do Laboratório Nacional de Redes de Computadores (LARC), indicado por seu diretor.

Membros eleitos são constituídos por:

- Dois membros de notória capacidade profissional, representantes dos pontos de presença da RNP (PoPs), eleitos pelo Conselho de Administração, mediante indicação do conjunto de PoPs de cada região; 
- Um representante dos associados, eleito na forma do artigo $8^{\circ}$ do estatuto da Associação;

- Um representante das instituições de ensino e pesquisa, usuárias dos serviços da RNP, indicado pelo Comitê de Usuários.

É importante ressaltar que a aplicação do questionário apresentou algumas limitações. Por se tratar de uma pesquisa feita com administradores de altos cargos de uma organização social, a quantidade de arquivos respondidos não correspondeu às solicitações em sua totalidade.

Como não há informação sobre quais são os endereços eletrônicos de cada diretor e membro do conselho no portal da Rede Nacional de Ensino e Pesquisa - RNP da internet, foi enviada uma mensagem realizando um pedido sobre essas informações pelo Sistema de Informações ao Cidadão que a página disponibiliza.

Após o retorno da instituição indicando os e-mails dos 5 diretores, foi também informado que o mesmo não poderia ser feito em relação aos conselheiros. A instituição se encarregaria de enviar os questionários para cada um dos membros do Conselho de Administração, já que não teria a permissão para disponibilizar os endereços eletrônicos destes.

Portanto, o primeiro contato foi realizado solicitando a participação dos empresários por meio do envio dos questionários por e-mail. Após recebidos alguns questionários respondidos, foi realizada uma nova tentativa. Dessa vez, agradecendo a participação daqueles que já tinham colaborado com a pesquisa.

Levando em consideração o processo da coleta de dados descrito acima, percebe-se então, que o resultado da análise foi formado pela interpretação dos questionários que retornaram com respostas.

Em seguida, a partir da coleta das respostas, foram verificadas as percepções dos diretores e membros do Conselho de Administração da organização social, em relação a contribuição do Comitê de Auditoria para a governança da instituição.

\section{DESCRIÇÃO E ANÁLISE DE DADOS}

2.1. Informações importantes sobre a RNP

A Rede Nacional de Ensino e Pesquisa (RNP), de acordo com o Relatório de Gestão Anual de 2018, está localizada na Avenida Lauro Muller 116 - 1103, Rio de Janeiro, RJ, foi qualificada como organização social por meio do Decreto $n^{\circ} 4.077$, de 9 de janeiro de 2002 . Tem como finalidade o desenvolvimento tecnológico da área de redes e suas aplicações, com o 


\section{Contabilidade}

foco orientado para o suporte às atividades de ensino, notadamente, na educação superior e na pesquisa.

Para isso, se constitui como a infraestrutura de rede de comunicação e computação para suporte à pesquisa brasileira, uma vez que propicia a integração de todo o sistema de pesquisa e ensino superior por meio de uma rede de alta capacidade, rica de serviços e aplicações. Por meio dessa rede nacional, ou backbone, chamada Rede Ipê, também são realizadas pesquisas para o desenvolvimento e teste de novas Tecnologias de Informação e Comunicação (TIC). Essas tecnologias constituem a base da nova sociedade do conhecimento; seu domínio e uso são essenciais para o desenvolvimento do País. Nesse sentido, a própria rede se constitui como um laboratório nacional no qual os experimentos de TIC são realizados, permitindo que seus resultados possam beneficiar mais rapidamente os clientes.

No mesmo relatório, é possível encontrar o organograma da instituição. A estrutura organizacional da entidade, como retratam as páginas 32 a 47, está estruturada na Figura 2. Figura 2: Estrutura Organizacional (RNP)




Fonte: Rede Nacional de Ensino e Pesquisa (RNP) (2019)

A estrutura organizacional da entidade, está estruturada nas seguintes categorias:

1. Gestão de Pessoas;

2. Gestão de Compras;

3. Gestão de Contratos;

4. Gestão de Serviços Administrativos;

5. Gestão de Controle patrimonial;

6. Gestão de Finanças;

7. Gestão de Riscos, Auditoria e Compliance;

8. Controladoria.

Para completo entendimento do estudo que compõe esse artigo, é interessante dar foco apenas a duas delas: Gestão de Finanças e Gestão de Riscos, Auditoria e Compliance.

O trabalho na área de Finanças da RNP é desenvolvido em três processos principais: financeiro, contábil e orçamentário.

O principal objetivo dessa área é garantir a transparência na segregação dos recursos e das receitas e dos custos e das despesas realizadas ao longo do ano, além de proporcionar um controle mais adequado das informações e que dê subsídio à tomada de decisão da Organização.

O processo financeiro é executado para atender as atividades de recebimentos, pagamentos, tesouraria, controle de fluxo de caixa, relacionamento com bancos, cobrança e análise da conformidade normativa e tributária nas aquisições efetuadas pela RNP. Além disso, dá suporte às atividades relacionadas à elaboração de prestações de contas exigidas nas obrigações contratuais. 
O processo contábil, por sua vez, preocupa-se com os lançamentos, as análises, a contabilização fiscal e do patrimônio social, assim como com a elaboração das demonstrações financeiras, a participação nos processos de auditoria e a publicação dos balanços auditados.

A partir de 2015, a área de Finanças passou a realizar o controle da execução orçamentária do Plano de Ação Anual da RNP.

Para 2016, se planeja realizar o projeto piloto da Gestão Estratégica de Custos, com o objetivo de aprimorar as informações gerenciais para tomadas de decisão, seja no âmbito dos clientes, seja no âmbito dos financiadores.

Em relação à Gestão de Riscos, Auditoria e Compliance (p. 45), desde 2002, a RNP realiza o processo de auditoria independente das demonstrações financeiras e, até 2013, realizou duas vezes a troca da empresa prestadora do serviço de auditoria, com base em procedimentos licitatórios regulares e conforme as orientações recebidas do Conselho de Administração da Organização, reforçando o conceito de excelência em governança corporativa buscado pela instituição.

Em 2015, a RNP continuou a ser auditada pela Ernst \& Young, para avaliação das demonstrações financeiras, asseguração limitada do fluxo de caixa financeiro e de contratos de conectividade, assim como a auditoria independente específica trabalhista e previdenciária.

Da mesma forma que nos anos anteriores, deu-se continuidade ao acompanhamento dos planos de ação para os apontamentos identificados desde 2011 e ainda não tratados até 2015. Com isso, em 2015, constatou-se eficácia média de cerca de 78\% dos planos propostos pelas áreas auditadas, resultado maior do que o verificado no exercício anterior, demonstrando que o aprendizado em controle e mitigação de risco está sendo internalizado.

A melhora no índice do indicador é atribuída à mitigação nos apontamentos envolvendo questões contábeis, administrativas e financeiras. No entanto, o número ainda é bastante influenciado pelo impacto da lenta redução nos apontamentos obtidos na auditoria trabalhista e previdenciária.

Em 2015, foi proposta pela Controladoria e aprovada pela Diretoria Executiva a realização de um projeto piloto de auditoria interna, para a implementação deste processo na RNP - não de forma imediata, mas por meio de uma equipe representativa da organização que testasse e avaliasse todo o processo, assim como também o prestador de serviços selecionado. O projeto foi realizado em 2015, de forma parcial, até as fases 4 e 5 programadas: realização da auditoria interna piloto em si, pela Deloitte Touche Tohmatsu, fornecedor adjudicado no processo de licitação e avaliação prévia para ajustes. 


\section{Contabilidade}

Um dos ajustes efetuados foi a troca da equipe de auditoria responsável, de Campinas para o Rio de Janeiro, minimizando problemas de custo, agilidade e atendimento.

Os dois processos corporativos que estão sendo auditados neste piloto são Planejamento e Execução de Programas de P\&D - Recorte GTs (envolvendo o Indicador 1 do Contrato de Gestão) e Planejamento e Execução do Plano Operacional (envolvendo o Indicador 5 do Contrato de Gestão).

As entregas finais do piloto constituem-se nos fluxogramas dos processos auditados pela Deloitte e mapeados ou desenhados durante os trabalhos, bem como os relatórios de auditoria com os apontamentos de controles, riscos, sugestões e recomendações dos auditores.

\subsection{Resultados dos questionários}

Do total de 15 administradores (5 diretores e 10 membros do Conselho de Administração), 20\% responderam ao questionário e 6\% informaram não saber responder com propriedade aos questionamentos acerca do tema "Comitê de Auditoria". O restante não retornou as tentativas de contato, nem prestou esclarecimento sobre o interesse em participar da pesquisa. Assim sendo, o perfil dos respondentes da pesquisa está representado no Quadro 3:

Quadro 3: Perfil dos Colaboradores

\begin{tabular}{|c|c|c|c|c|c|}
\hline IDADE & $\begin{array}{l}<25 \text { anos } \\
-\end{array}$ & \multicolumn{3}{|c|}{$\begin{array}{l}\text { Entre } 25 \text { e } 50 \text { anos } \\
-\end{array}$} & $\begin{array}{l}>50 \text { anos } \\
100 \%\end{array}$ \\
\hline FORMAÇÃO & $\begin{array}{l}\text { Graduação/ Esı } \\
33 \%\end{array}$ & zação & $\begin{array}{l}\text { Mestrado } \\
67 \% \\
\end{array}$ & $\begin{array}{l}\text { Doutorado } \\
- \\
\end{array}$ & $\begin{array}{l}\text { Pós- } \\
\text { Doutorado } \\
\text { - }\end{array}$ \\
\hline $\begin{array}{l}\text { ÁREA } \\
\text { CONHECIMENTO }\end{array}$ & $\begin{array}{l}\text { Administração } \\
33 \%\end{array}$ & $\begin{array}{l}\text { Economia } \\
-\end{array}$ & $\begin{array}{l}\text { Contabilidade } \\
\text { - }\end{array}$ & $\begin{array}{l}\text { Engenharia } \\
67 \%\end{array}$ & $\begin{array}{l}\text { Outras } \\
-\end{array}$ \\
\hline $\begin{array}{l}\text { EXPERIÊNCIA } \\
\text { PROFISSIONAL }\end{array}$ & $\begin{array}{l}<10 \text { anos } \\
- \\
\end{array}$ & $\begin{array}{l}\text { Entre } 10 \mathrm{e} \\
-\end{array}$ & 5 anos & & $\begin{array}{l}>25 \text { anos } \\
100 \%\end{array}$ \\
\hline $\begin{array}{l}\text { CARGO QUE EXERCEU } \\
\text { POR MAIS TEMPO }\end{array}$ & $\begin{array}{l}\text { Presidência/ } \\
\text { Diretor-Geral } \\
33 \%\end{array}$ & $\begin{array}{l}\text { Secretário } \\
\text { Diretor } \\
67 \%\end{array}$ & Executivo/ & $\begin{array}{l}\text { Coordenação/ } \\
\text { Gerência } \\
\text { - }\end{array}$ & $\begin{array}{l}\text { Outros } \\
-\end{array}$ \\
\hline
\end{tabular}

Fonte: dados da pesquisa (2018) 


\section{Revista

Da análise do Quadro 3, infere-se que os executivos da OS pesquisada tem idade acima de 50 anos, a maioria (67\%) são engenheiros e possuem experiência profissional acima da 25 anos. Nas pergundas fechadas foi perguntado se a instituição possuía um Comitê de Auditoria e, caso tivesse, escolhessem a afirmativa que mais se aproximaria da razão que incentivou a criação, dentre as opções:

- preocupação em atender totalmente às exigências dos órgãos internacionais;

- adoção de melhores práticas de governança corporativa;

- necessidade de um grupo de funcionários com profundo conhecimento técnico financeiro para avaliação das demonstrações contábeis da organização;

- outro.

Foi informado, por meio da resposta, que a organização optou por não constituir o comitê, portanto, a segunda pergunta referente ao motivo da criação, não era aplicável ao caso dessa instituição. Este achado corrobora o estudo de Santos, Schmeider e Cunha (2017) que ao analisarem empresas listadas na bolsa de valores, concluíram que, de modo geral, a criação do comitê de auditoria, ainda, não é uma prática institucionalizada pelas empresas brasileiras.

Quando questionados sobre o grau de necessidade da constituição do Comitê de Auditoria para a governança corporativa da organização social, por meio de uma pergunta também fechada, os resultados foram os seguintes:

\begin{tabular}{|l|l|}
\hline DISPENSÁVEL* & INDISPENSÁVEL \\
\hline $\mathbf{6 7 \%}$ & $\mathbf{3 3 \%}$ \\
\hline
\end{tabular} *aso o Conselho Fiscal seja capaz de exercer as funções que seriam do Comitê de Auditoria.

Ou seja, a razão pela qual se optou por não constituir o Comitê de Auditoria pode ser explicada pelo fato de que a maior parte dos gestores acredita que a configuração da administração atual já apresenta eficiência necessária para supervisionar os controles internos e a gestão de riscos, tornando, assim, a criação do comitê dispensável. Este achado contradiz o achado do estudo de Teixeira, Camargo e Vicente (2016) que indica eficiência e eficácia dos controles internos em empresas que constituíram o Comitê de Auditoria.

As duas questões seguintes (4 e 5) eram do tipo aberta. Na primeira delas foi solicitado aos respondentes que discorressem sobre os pontos positivos e negativos da implantação do Comitê de Auditoria.De acordo com a opinião dos colaboradores, como pontos positivos e pontos negativos, foram apontados os seguintes aspectos: 
Quadro 4: Pontos positivos e negativos do Comitê de Auditoria apontados pelos colaboradores da pesquisa

\begin{tabular}{|c|l|}
\hline \multicolumn{1}{|c|}{ Pontos positivos } \\
\hline 1 & $\begin{array}{l}\text { Melhor disseminação das informações que envolvem conhecimento compartilhado de processos } \\
\text { e suas entregas em uma visão cliente - fornecedor. }\end{array}$ \\
\hline 2 & Aponta para pontos de atenção. \\
\hline 3 & Traz credibilidade ao controle e qualidade das demonstrações financeiras. \\
\hline 4 & Aumento da confiança do Conselho de Administração sobre a gestão dos riscos corporativos. \\
\hline 5 & Permite alcançar maiores níveis de governança corporativa. \\
\hline 1 & $\begin{array}{l}\text { Comitês são ineficazes na sua essência ou tentam exercer autoridade sobre as pessoas e áreas ou } \\
\text { redutos de pensamentos deslocadas da prática. }\end{array}$ \\
\hline 2 & Implica em custos adicionais à operação da organização. \\
\hline 3 & $\begin{array}{l}\text { Maior complexidade para o ambiente da gestão corporativa de uma organização social, } \\
\text { possivelmente de forma ineficiente }\end{array}$ \\
\hline 4 & Sobreposição com funções do Conselho de Administração, que é não remunerado. \\
\hline
\end{tabular}
Fonte: dados da pesquisa (2018).

Por sua vez, a questão 5 indagava se, na opinião dos respondentes, existiria alguma função do Comitê de Auditoria que o Conselho Fiscal não fosse capaz de exercer. Nesse ponto, as concepções se mostraram bastante divididas, já que os posicionamentos geraram resultados igualmente proporcionais para as opções "Não", "Possivelmente" e "Sim".

Na ocasião em que foi respondido "não", explicou-se que, como já mencionado, a gestão não via necessidade do citado Comitê. Além disso, boa governança pressupõe uma boa organização, guiada por uma estratégia sempre atualizada, divisão de tarefas movidas por processos permanentemente em constante evolução e atribuições bem definidas da participação de cada área e pessoas com competência adequadas ao negócio.

Portanto, na opinião dos respondentes, a aferição de boas práticas deve estar, no máximo, com uma área de controladoria que, apoiada em uma auditoria externa independente, avalia o curso da ação, os riscos quantificados por projeções e tendências. Ao final desse processo, remetem para a função de planejamento suas orientações para propor ações de preenchimento de lacunas tanto na quantidade de recursos (humanos, materiais e de conhecimento) quanto na qualidade desses adequados para a superação dos óbices identificados.

A partir dos esclarecimentos prestados acima, conclui-se que, para esta parcela dos colaboradores da pesquisa, não existe uma função do comitê que o Conselho Fiscal (ou Conselho de Administração, como é no caso dessa instituição) não seja capaz de exercer, isso quando conta com profissionais equipados, tanto com técnicas avançadas quanto com experiência, para suprir as lacunas que teoricamente poderiam ter surgido com a escolha de não criar o comitê. 
O respondente que respondeu "possivelmente", se justificou informando que as funções do Conselho Fiscal são atualmente desempenhadas pelo Conselho de Administração apoiado pela auditoria externa independente, realizada por empresa de primeira linha (E\&Y). E que isso representaria, portanto, grande credibilidade. Porém, não saberia dizer com convicção se de fato existe uma função que o Conselho de Administração não seria capaz de exercer.

Quando a resposta foi "sim", o único ponto apontado seria a total independência, uma característica importantíssima do comitê, que o torna capaz de opinar de forma isenta sobre diversos itens de segurança corporativa da empresa.

No que diz respeito às questões seguintes, sua composição era de algumas opções de respostas em escala Likert. Ou seja, os 4 itens finais do questionário eram compostos por uma afirmação cada. Em seguida de sua leitura, os gestores deveriam, de acordo com seu julgamento, escolher um grau de consentimento/rejeição marcando uma opção dentro da escala pré-estabelecida ("Concordo plenamente", "Concordo em parte", "Não concordo nem discordo", "Discordo em parte", "Discordo plenamente"). Obtiveram-se os resultados a seguir:

- Afirmação 1: As atribuições do Conselho Fiscal e do Comitê de auditoria são distintas.

Tabela 1 - Percepção dos Executivos sobre o papel do Comitê de Auditoria e do Comitê fiscal

\begin{tabular}{|c|c|c|c|c|c|}
\hline Item & $\begin{array}{c}\text { Concordo } \\
\text { plenamente }\end{array}$ & $\begin{array}{c}\text { Concordo } \\
\text { em parte }\end{array}$ & $\begin{array}{c}\text { Nem } \\
\text { concordo nem } \\
\text { discordo }\end{array}$ & $\begin{array}{c}\text { Discordo em } \\
\text { parte }\end{array}$ & $\begin{array}{c}\text { Discordo } \\
\text { plenamente }\end{array}$ \\
\hline 1 & $33,0 \%$ & - & $67,0 \%$ & - & - \\
\hline 2 & - & $67,0 \%$ & $33,0 \%$ & - & - \\
\hline 3 & - & $33,0 \%$ & $67,0 \%$ & - & - \\
\hline 4 & - & $33,3 \%$ & $33,3 \%$ & $33,3 \%$ & - \\
\hline
\end{tabular}

Fonte: dados da pesquisa (2018)

Os resultados encontrados no Tabela 1 acima mostram que 33\% dos participantes da pesquisa concordam plenamente com a afirmação, enquanto $67 \%$ não concordam nem discordaram. Ou seja, enquanto a maioria dos executivos permaneceu indiferente em relação à afirmação, outra parte deles acredita que o Conselho Fiscal e o Comitê de Auditoria possuem sim funções distintas.

Ao contrário do que foi observado nos resultados acima, a pesquisa de Furuta e Silva (2010) mostrou que pouco mais da metade dos executivos das empresas acredita que, de certa forma, as funções não são distintas.

Segundo o IBCG (2015), as funções do Comitê de auditoria estão relacionadas a preservar a confiabilidade das demonstrações contábeis. Consequentemente, o órgão acaba se tornando um mecanismo de proteção para os stakeholders, ou seja, os usuários da informação. 


\section{Revista

Em um ambiente corporativo, isso significa uma garantia maior para os investidores, além de evitar fraudes e escândalos.

Os stakeholders de uma Organização Social são todos aqueles que se interessam em ter acesso a ela. De acordo com a Lei de Acesso à Informação, a gestão deve ser transparente e propiciar amplo acesso à informação e sua divulgação. Essa regra é aplicada às entidades privadas sem fins lucrativos que recebam, para realização de ações de interesse público, recursos públicos diretamente do orçamento ou mediante subvenções sociais, contrato de gestão, termo de parceria, convênios, acordo, ajustes ou outros instrumentos congêneres. Portanto, as organizações não devem prestar contas apenas com seu órgão fiscalizador, mas também com toda a sociedade. É comum que as entidades divulguem em seus endereços eletrônicos os Relatórios de Gestão Anuais. Nesses relatórios é possível ter acesso a informações como demonstrações contábeis, indicadores de desempenho e informações sobre o contrato de gestão.

Ainda de acordo com o IBGC, o Conselho Fiscal não se assemelha ao Comitê de auditoria nesses aspectos, já que, essencialmente, suas atribuições estão focadas em preservar o valor da empresa.

- Afirmação 2: O Comitê de Auditoria pode ser visto como um mecanismo de monitoramento da gestão da organização social.

Ao serem questionados se o comitê pode ser um instrumento para monitorar a gestão, $67 \%$ dos colaboradores da pesquisa concordaram em parte com a afirmação e $33 \%$ deles nem concordou nem discordou. Portanto, a maioria dos executivos, de certa forma, considera que o comitê pode ser um mecanismo de monitoramento.

O resultado da pesquisa de Furuta e Santos (2010) indicou, da mesma forma, a posição da maioria concordando, plenamente ou em parte, com a afirmação. Porém, o estudo chamou atenção para uma observação feita por um dos colaboradores da pesquisa. Na opinião dele, na verdade, o monitoramento da gestão seria uma função do Conselho de Administração, e que esse seria auxiliado pelo Comitê de auditoria.

- Afirmação 3: A utilização do Conselho Fiscal adaptado em substituição ao Comitê de Auditoria poupa custos para aorganização social. 


\section{Revista

De acordo com o Tabela 1,33\% dos executivos concordam em parte com a afirmação de que adaptar o Conselho Fiscal com as funções do Comitê de Auditoria acarreta menos gastos de recursos, do que a criação do comitê. E 67\% deles nem concorda nem discorda. De certa forma, apesar de uma parcela dos gestores acreditar que a criação do comitê traria mais gastos à organização, esse fator não parece ter sido decisivo para que escolhessem não criar o comitê.

Na pesquisa de Furuta e Santos (2010), foi informado que não houve consenso nas respostas obtidas. Os executivos que participaram do estudo acreditam que os custos variam de organização para organização, e depende se a empresa já possui ou não um Conselho Fiscal estruturado e capacitado.

- Afirmação 4: O Conselho Fiscal que atua com funções de Comitê de Auditoria é mais adaptável ao ambiente de negócios corporativos (com fins lucrativos) do que a formação do Comitê de Auditoria em organizações sociais.

A afirmação 4 foi adaptada em relação aà original, que fazia parte da pesquisa de Furuta e Santos (2010). Essa afirmação teve como objetivo testar as opiniões dos executivos em relação à comparação do ambiente corporativo ao seu próprio ambiente (de terceiro setor).Os resultados ficaram igualmente divididos em 33,3\% para "Concordo em parte", "Nem concordo nem discordo" e "Discordo em parte".

O terceiro setor presta contas com seu órgão fiscalizador e também para a sociedade, garantindo o acesso à informação. Porém, no ambiente corporativo, existe a figura do investidor, o principal stakeholder, que aplica diretamente seus recursos na organização. E de certa forma, após tantos casos de fraudes na década passada, o investidor se tornou mais exigente. Com isso, são criados suportes para garantir que as reivindicações daqueles que possuem participações nas empresas sejam atendidas. Isso inclui a confiabilidade das informações divulgadas pelos administradores. Com a criação do Comitê de Auditoria, a confiabilidade aumenta.

Já no caso das Organizações Sociais, não existe essa pressão dos investidores. Ou seja, o perfil dos seus stakeholders é diferente. Apesar de que a veracidade das demonstrações contábeis deve ser garantida da mesma forma, a ausência dessa pressão faz toda a diferença. Portanto, isso pode indicar por quais motivos a organização optou por não constituir um Comitê de Auditoria, já que, segundo seus gestores, o Conselho de Administração é capacitado para absorver essas funções. Tal fato é observado nos estudos de Reyes, Cunha e Cecon (2018) e Rendon e Garcia (2015). 


\section{CONSIDERAÇÕES FINAIS}

O estudo, baseado na pesquisa de Furuta e Santos (2010), teve como objetivo obter as percepções de conselheiros e diretores de uma Organização Social do governo federal, sobre a importância da criação de um Comitê de Auditoria para elevar os níveis de governança corporativa da instituição. A pesquisa original pretendia identificar se a preferência dos executivos estava concentrada na criação do Comitê de Auditoria ou na utilização do Conselho Fiscal Adaptado.

O alcance do primeiro objetivo específico sobre a importância (dispensável ou indispensável para a gestão da OS) foi respondidoa partir dos achados da pesquisa. Assim sendo, concluiu-se que o Comitê de Auditoria é relevante para a governança de uma Organização Social (OS), mas a sua instalação não é prioridade na organização social estudada. Sendo assim, levando em consideração as orientações apresentadas no Código das Melhores Práticas de Governança Corporativa do IBGC (2015), o qual defende a ideia de que o Comitê de Auditoria é um órgão relevante de assessoramento ao conselho de administração, e que este oferece suporte ao monitoramento da qualidade do processo contábil, esse posicionamento do IBGC (2015) reforça a percepção dos respondentes de que a criação de um Comitê de Auditoria pode contribuir para a elevação dos níveis de governança corporativa de uma organização.

Feitas as análises dos questionários respondidos pelos colaboradores da pesquisa, pode-se concluir que, como foi sugerido pelo IBGC (2015), a criação do comitê é considerada pelos executivos um mecanismo de governança, como demonstrou o resultado encontrado, segundo o qual $67 \%$ dos executivos concordam em partes com a afirmação de "O Comitê de Auditoria pode ser visto como um mecanismo de monitoramento da gestão da organização social". Assim como foi apontado por um deles em questão aberta que "alcançar maiores níveis de governança corporativa" seria um dos pontos positivos de constituir um Comitê de Auditoria.

Em síntese, conforme abordado no referencial teórico, por exemplo, nos estudos de Reyes, Cunha e Cecon (2018), Santos, Schmeider e Cunha (2017), Baioco e Almeida (2017), Teixeira, Camargo e Vicente (2016), IBGC (2015) e Rendon e Garcia (2015) e após análise da contribuição dos respondentes, a criação de um Comitê de Auditoria, se implementado, pode contribuir para a boa governança de uma OS no auxilio do monitoramento do cumprimento das leis, regulamentos e sistemas de controle interno; no gerenciamento de riscos; dos aspectos de ética e conduta; da qualidade do processo contábil; e na supervisão das atividades da auditoria interna. 


\title{
Revista

Porém, de certa forma, as organizações sociais apresentam a tendência de ter uma preocupação menor com a gestão e governança do que as empresas corporativas e isso pode ser explicado pela ausência de fatores como a concorrência do mercado e a necessidade de distribuição de lucros. Portanto, percebe-se um modelo hibrido de governança, onde não existe uma cobrança do principal (a sociedade), mas devido ao contrato de gestão as OS devem apresentar relatório de alcance das metas de desempenho pactuadas no Contrato de Gestão.

Foi possível perceber, também, que os relatórios de gestão anuais feitos pelas organizações focam em alcançar metas estabelecidas e não diretamente na qualidade da gestão. Portanto, os níveis de governança no contexto atual, ainda não podem ser considerados indicativos relevantes da qualidade da prestação de serviços das O.S.s.As limitações que o estudo enfrentou foram as dificuldades em aplicar questionários aos detentores de altos cargos na Organização Social escolhida, já que o retorno das solicitações para participação da pesquisa se torna difícil de ser recebido, minimizando assim, a amostra da pesquisa.

Para futuras pesquisas, fica registrada a sugestão de aplicar um questionário sobre a importância do Comitê de Auditoria para os membros do conselho de administração e diretores de outras Organizações Sociais do governo federal e, se possível, à todas elas. E após essa aplicação, estabelecer um comparativo aos resultados encontrados na presente pesquisa e também aqueles achados no estudo de Furuta e Santos (2010).

\begin{abstract}
Third sector entities, called Social Organizations, whose activities are directed to teaching, scientific research, technological development, protection and preservation of the environment, culture and health have a hybrid governance model. In this regard, the creation of an Audit Committee contributes as an advisory body to the Board of Directors. Therefore, this study aims to analyze the opinion of the directors and members of the Board of Directors on the importance of creating an Audit Committee for a third sector entity and was based on the work of Furuta and Santos (2010). Data collection was done through the application of questionnaires by electronic mail. The constitution of an Audit Committee was assessed by $67 \%$ of the research collaborators as dispensable if the Fiscal Council were able to perform its duties. As positive aspects of the creation of the committee, the executives pointed out: bring credibility to the control and quality of the financial statements and achieve higher levels of corporate governance. Therefore, it was concluded that the installation of the Audit Committee is not a priority despite the contribution to improving OS Governance studied. Finally, it is clear that the annual management reports of social organizations focus on achieving goals rather than presenting the quality of management.
\end{abstract}

Keywords: Audit Committee; Social Organization; Corporate Governance; Public Governance. 


\section{REFERÊNCIAS}

Associação de Comunicação Educativa Roquette Pinto (ACERP). Decreto de Qualificação e Contrato de gestão. Disponível em: http://roquettepinto.org.br/ >. Acesso em: 20 de junho de 2016

Associação Rede Nacional de Ensino e Pesquisa (RNP). Decreto de Qualificação e Contrato de gestão. Disponível em: <https://www.rnp.br/arquivos/documents/RNP-RelatorioPlurianual-2011-2019.pdf>. Acesso em: 17 de dezembro de 2019

Baioco, V. G., \& Almeida, J. E. F. (2017). Efeitos do comitê de auditoria e do conselho fiscal na qualidade da informação contábil no Brasil. Revista Contabilidade \& Finanças - USP, 28(74), 229-248.

BRASIL. LEI COMPLEMENTAR No 101 (Lei da Responsabilidade Fiscal) de 04/05/2000. Disponível em: <http://www.planalto.gov.br>. Acesso em: 20 de junho de 2016

BRASIL. Lei n. ${ }^{\circ}$ 9.637/98 (Lei das Organizações Sociais, de 15/05/1998. Disponível em: <http://www.planalto.gov.br>.

Centro Brasileiro de Pesquisa em Avaliação e Seleção e de Promoção de Eventos (CEBRASPE). Decreto de Qualificação e Contrato de gestão. Disponível em: < http://www.cespe.unb.br >. Acesso em: 20 de junho de 2016

Centro de Gestão e Estudos Estratégicos (CGEE). Decreto de Qualificação e Contrato de gestão. Disponível em: <https://www.cgee.org.br/>. Acesso em: 20 de junho de 2016.

Centro Nacional de Pesquisas em Energia e Materiais/ Associação Brasileira de Tecnologia de Luz Síncrotron (CNPEM/ABTLuS). Decreto de Qualificação e Contrato de gestão. Disponível em: < http://cnpem.br>. Acesso em: 20 de junho de 2016

COUTINHO, NINA Novaes. As organizações sociais e o contrato de gestão. Revista de Direito Público. Londrina, 2006.

Cunha, P. R., Pletsch, C. S., \& Silva, A. (2015). Relação entre as Características da Empresa, do Comitê de Auditoria e do Auditor Independente com o Prazo de Publicação das Demonstrações Financeiras. Revista de Educação e Pesquisa em Contabilidade, 9(4), 415-429. DI PIETRO, Maria Sylvia Zanello. Direito Administrativo. 14.ed. São Paulo: Editora Atlas, 2002a.

Empresa Brasileira de Pesquisa e Inovação Industrial (EMBRAPII ). Decreto de Qualificação e Contrato de gestão. Disponível em: < http://embrapii.org.br/ >. Acesso em: 20 de junho de 2016

FIGUEIREDO, Lúcia Valle. Curso de Direito Administrativo. 7. Ed. São Paulo: Malheiros, 2003.

FURUTA, Fernanda e SANTOS, Arivaldo. Comitê de Auditoria versus Conselho Fiscal Adaptado: a visão dos analistas de mercado e dos executivos das empresas que possuem ADRs. São Paulo: Revista Contabilidade e Finanças, USP, 2010.

GONÇALVES, Wagner. Parecer sobre Terceirização e Parcerias na Saúde Pública. Disponível em: <www.datasus.gov.br/cns/temas/WAGTERC.htm>. Acesso em: 14 mar. 2005.

IBGC. Instituto Brasileiro de Governança Corporativa. Guia de orientações para melhores práticas de Comitês de Auditoria. Coordenação: Roberto Lamb e João Verner Juenemann. São Paulo: IBGC, 2015a

Instituto de Desenvolvimento Sustentável Mamirauá (IDSM). Decreto de Qualificação e Contrato de gestão. Disponível em: < http://www.mamiraua.org.br/pt-br $>$. Acesso em: $20 \mathrm{de}$ junho de 2016

Instituto Nacional de Matemática Pura e Aplicada (IMPA). Decreto de Qualificação e Contrato de gestão. Disponível em: < http://www.impa.br/opencms/pt/ >. Acesso em: 20 de junho de 2016 


\section{Contabilidade}

MEIRELLES, Hely Lopes. Direito Administrativo Brasileiro. 29. ed. São Paulo: Editora Malheiros, 2001.

NÓBREGA, Maílson. In Revista do Ministério da Administração Federal e Reforma do Estado, 2000.

RENDON, María Enriqueta MANCILLA; GARCIA, María Luisa SAAVEDRA. Corporate governance and the audit committee as part of Corporate Social Responsibility. Contad. Adm, México , v. 60, n. 2, p. 486-506, June 2015 . Available from $<$ http://www.scielo.org.mx/scielo.php?script=sci_arttext\&pid=S0186-

10422015000200486\&lng=en\&nrm=iso $>$. access on $17 \quad$ Dec. 2019. http://dx.doi.org/10.1016/S0186-1042(15)30011-5.

REYES, M. C. R.; CUNHA, P. R. DA; RODRIGUES JUNIOR, M. M.; CECON, B. CARACTERÍSTICAS DO CONSELHO DE ADMINISTRAÇÃO E DO COMITÊ DE AUDITORIA DAS EMPRESAS LISTADAS NA BM\&FBOVESPA. REVISTA AMBIENTE CONTÁBIL - Universidade Federal do Rio Grande do Norte - ISSN 2176-9036, v. 10, n. 2, p. 404-422, 15 jun. 2018.

ROCHA, Silvio Luis da. Terceiro Setor. São Paulo: Editora Malheiros, 2003..

SANTOS, Vanderlei dos; SCHMEIDER, Camila Francieli; CUNHA, Paulo Roberto da. Características do comitê de auditoria: um estudo nas empresas listadas na BM\&FBovespa. REVISTA CATARINENSE DA CIÊNCIA CONTÁBIL, [S.1.], v. 16, n. 49, dez. 2017. ISSN 2237-7662.

Disponível

em: <http://revista.crcsc.org.br/index.php/CRCSC/article/view/2449/1959>. Acesso em: 17 dez. 2019. doi:http://dx.doi.org/10.16930/rccc.v16n49.2449.

SANTOS, Vanderlei dos; SCHMEIDER, Camila Francieli; CUNHA, Paulo Roberto da. Características do comitê de auditoria: um estudo nas empresas listadas na BM\&FBovespa. REVISTA CATARINENSE DA CIÊNCIA CONTÁBIL, [S.1.], v. 16, n. 49, dez. 2017. ISSN 2237-7662. Disponível em: 〈http://revista.crcsc.org.br/index.php/CRCSC/article/view/2449>. Acesso em: 17 dez. 2019. doi:http://dx.doi.org/10.16930/rccc.v16n49.2449.

SCHEDLER, A. 1999. " Conceptualizing accountability" . In: ; Diamond, L.; Plattner, M. F. (orgs.). The self-restraining state: power and accountability in new democracies. Boulder/London: Lynne Rienner.

TCU. Tribunal de Contas da União. Referencial Básico de Governança Aplicável a Órgãos e Entidades da Administração Pública. Brasília: 2013.

TEIXEIRA, Bruna; CAMARGO, Raphael Vinicius Weigert; VICENTE, Ernesto Fernando Rodrigues. Relação entre as características do comitê de auditoria e a qualidade da auditoria independente - DOI: http://dx.doi.org/10.16930/2237-7662/rccc.v15n44p60-74. REVISTA CATARINENSE DA CIÊNCIA CONTÁBIL, [S.1.], v. 15, n. 44, p. p. 60-74, abr. 2016. ISSN 2237-7662. Disponível em: 〈http://revista.crcsc.org.br/index.php/CRCSC/article/view/2177>. Acesso em: 17 dez. 2019. 